\title{
17. APTIAN AND ALBIAN BENTHIC FORAMINIFERS OF LEG 40, SITES 363 AND 364, SOUTHERN ATLANTIC
}

\author{
Viera Scheibnerová, Geological and Mining Museum, Geological Survey of New South Wales, \\ Department of Mines, Sydney, Australia
}

\begin{abstract}
Aptian/Albian (?early Cenomanian) foraminifers of Leg 40 Sites 363 and 364 are composed of species also known from India, South Africa, DSDP sites in the Indian Ocean and especially the Great Australian Basin, Australia, thus proving that the Southern Atlantic formed part of the Austral Biogeoprovince as presently understood (Figure 1). Because these foraminifer faunas could have only immigrated into the South Atlantic from the south, a southern marine connection must have existed. The opening in this southern marine connection may be dated by the Angolan evaporites and the Aptian foraminifers. However, the beginning of northern marine connection cannot purely be dated by foraminifers because even Late Cretaceous benthic foraminifer faunas at Sierra Leone Rise (Leg 3, Site 13) are still of clearly Austral nature. The planktonic component in these faunas and also on the northern flank of the Walvis Ridge (Site 363) have some forms which could have only come from more northerly tropical zones (Scheibnerová, 1973; Todd, 1970). These planktonic forms, however, bear signs of nontropical planktonics; i.e., they are smaller, less ornamented, specifically impoverished, and dominated by Globigerina-like forms. This supports my earlier conclusion (Scheibnerova, 1973) that a substantial northward shift of the African Plate occurred and an analog of the cool Benguela current existed in the Late Cretaceous explaining the Austral nature of the Late Cretaceous foraminifers.
\end{abstract}

\section{INTRODUCTION}

The South Atlantic Ocean adjacent to the African continent is divided into two major basins, the Cape Basin and the Angola Basin, by the prominent aseismic Walvis Ridge. Leg 40 of DSDP set out to determine the early Cretaceous to Recent evolution of these basins and to evaluate the role of the Walvis Ridge in their early history. It is now agreed that since the Early Cretaceous the Atlantic has widened from a long narrow basin, only slightly wider than the present Gulf of Aden, to the major ocean it is today. In the earliest Cretaceous, the two structural basins were almost closed-the Angola Basin to the north (Africa and South America were still sliding past each other along a complex system of transform faults), and the Cape Basin to the south, where a tip of South Africa was similarly being transformed past the Falkland Plateau.

The Angola Basin contains the deepest depression of the eastern South Atlantic. To the south it is isolated almost entirely from the Cape Basin by the highstanding Walvis Ridge, and to the west it is barred from the Brazil and Argentine basins by the broad central zone of the Mid-Atlantic Ridge. Because of a high degree of isolation, the oceanic bottom water mass of this basin is significantly warmer and hence appears less corrosive to carbonate skeletal sedimentary components than that of the rest of the Atlantic Ocean basins.

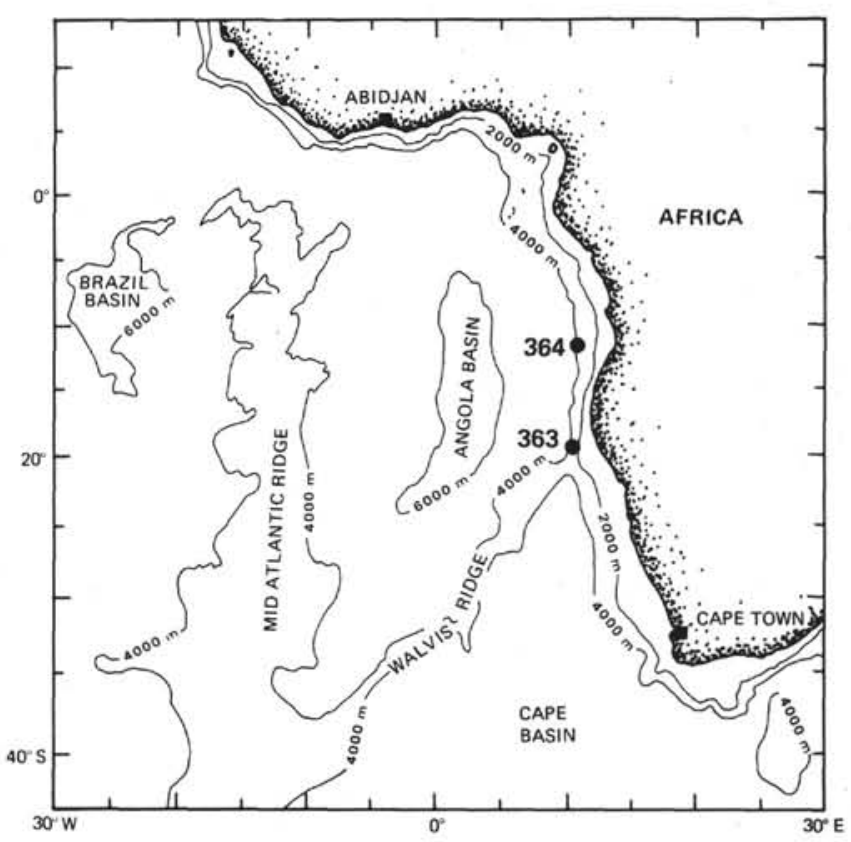

Figure 1. Location of Sites 363 and 364 of Leg 40.

The Cretaceous foraminifers I have studied for this report came from Sites 363 and 364. Site 363 is located close to the crest of an isolated basement high along the 
north-facing escarpment of the Frio Ridge segment of the Walvis Ridge (latitude $19^{\circ} 39^{\prime} \mathrm{S}$, longitude $09^{\circ} 03^{\prime} \mathrm{E}$, water depth $2248 \mathrm{~m}$ ). Site 364 is in the Angola Basin, some $10 \mathrm{~km}$ landward of an abrupt marginal escarpment that marks the presumed outer limit of a massive layer of salt and evaporites along the continental margin of southwest Africa (latitude $11^{\circ} 34^{\prime} \mathrm{S}$, longitude $11^{\circ} 58^{\prime} \mathrm{E}$, water depth, $\left.2448 \mathrm{~m}\right)$.

\section{SPECIES DISTRIBUTION}

From Site 363 I examined 34 samples from Cores 26 to 40 (Figure 2). The age range of these samples is discussed below. All contain benthic and planktonic foraminifers.

Especially characteristic are the following species: Anomalina indica, Clavulina gabonica, Hergottella jonesi, Discorbis sp., Gavelinella ex. gr. intermedia, Lingulogavelinella $\mathrm{cf}$. albiensis, L. frankei africana, Orithostella australiana, $O$. indica, Osangularia utaturensis, Patellina africana, Patellinella australis, Psuedopatellinella howchini, Verneuilina howchini.
Many other agglutinated species and nodosariids known from the coeval Austral sediments (Scheibnerová, 1971 a, b; 1973 a, b) on adjacent land also occur.

From Site 364, some 28 samples were studied from Cores 24-41 (Figure 3). Benthic foraminifers dominate the assemblages and are mainly composed of calcareous forms. These were known to occur in coeval sediments on adjacent land and in DSDP samples from the Indian Ocean (Scheibnerová, 1974 a, b).

Especially characteristic are: Charltonina sp., Clavulina gabonica, Discorbis sp., Gavelinella ex. gr. intermedia, G. oodnadattaensis, Gyroidinoides primitiva, Lingulogavelinella frankei, Orithostella indica, Osangularia occidentalis, O. utaturensis, Pseudolamarckina sp., Spirovolivina australis. When compared with foraminifer species of Site 363 some differences are noted in specific composition. The genus Lingulogavelinella is represented in Site 364 by the typical species frankei instead of frankei africana. This difference may have stratigraphic

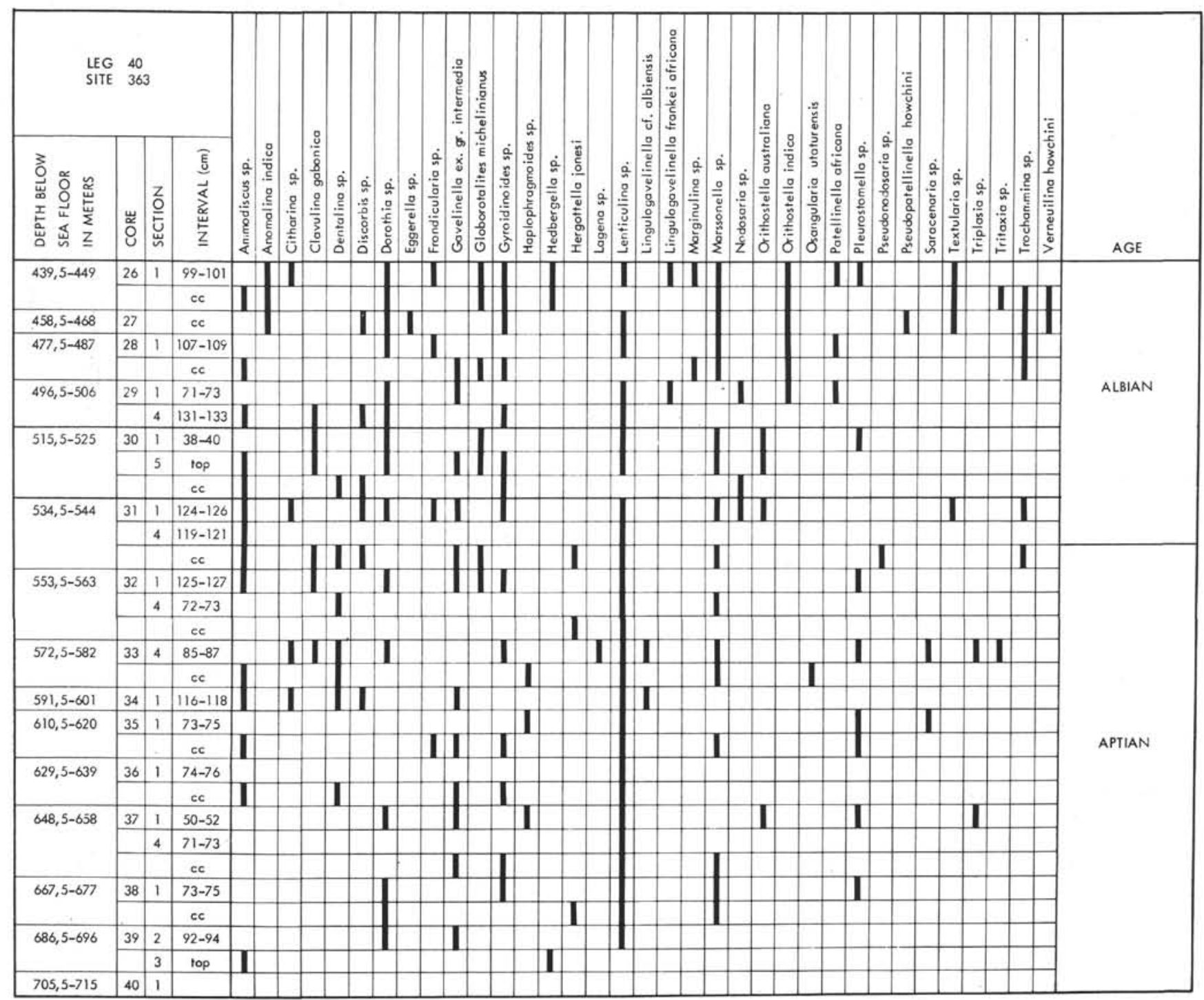

Figure 2. Distribution of Albian to Aptian benthic foraminifers at Site 363. 


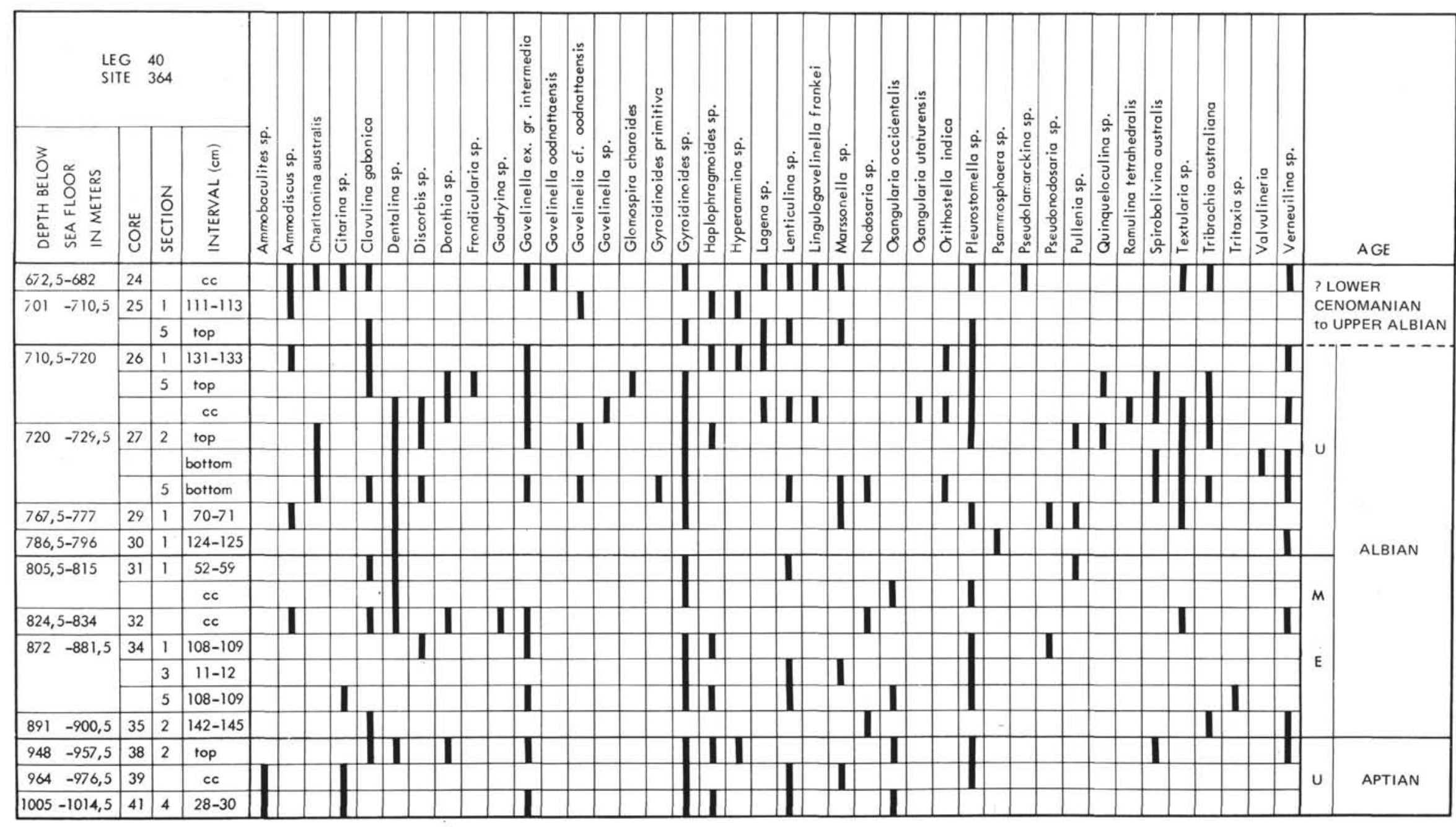

Figure 3. Distribution of Albian to Aptian benthonic foraminifera in Site 364. 
implications as frankei africana is essentially a middlelate Albian species while frankei is a late AlbianCenomanian species; however, this alone does not explain the complete lack of $L$. frankei at Site 363 Therefore, other reasons, especially ecological (such as depth, or composition of the substrate) have to be taken into consideration. Further, Spirobolivina, Osangularia occidentalis, Charltonina sp., and Gavelinella oodnadattaensis do not occur at Site 363. On the other hand, Aptian sediments of Site 364 do not contain Hergottella jonesi. However, such species as Orithostella indica, Gavelinella ex gr. intermedia, Discorbis sp., Gyroidinoides primitiva, and many agglutinated and nodosariid species occur at both sites. This difference is quite interesting, because foraminifer assemblages of both sites are represented by nontropical, Austral forms, and both sites therefore belong in the Austral Biogeoprovince. This means that a marine connection between South Africa and Australia must have existed at that time as this was the only route through which these benthic foraminifers could have migrated. It must be emphasized here, that the composition of both benthic and planktonic foraminifer assemblages is identical with those of other parts of the Austral Biogeoprovince, especially the Indian Ocean and adjacent areas such as South Africa, Peninsular India, and Australia (Lambert and Scheibnerová, 1974; Scheibnerová, 1972a, b, 1974a, b, 1976; Narayanan and Scheibnerová, 1975); less well known are South America and New Zealand. The nature and composition of the Leg 40 foraminifer assemblages show no influence from the tropical biogeoprovince; such shallow tropical benthic elements as Orbitolina are missing here, accompanied by the lack of tropical planktonic forms (Scheibnerová, 1971a, b). This implies that there were no marine connections to the north during the Early Cretaceous and Cenomanian. From ammonite faunas, Reyment (1969) postulated that the connection between the southern and northern Atlantic commenced in the Turonian. However, the situation was more complex than this. In another publication (Scheibnerová, 1973a) I have analyzed upper Cretaceous foraminifers from the Sierra Leone Rise (DSDP Leg 3, Site 13). Here, the benthic foraminifer species are completely Austral in their nature and composition and the planktonic component is typically impoverished; however, in the Late Cretaceous some of the eastern southern Atlantic faunas already contained elements such as some species of globotruncanids which could only be derived from the tropical zone (see Todd, 1970), although, at the same time the nature of these was typically Austral. Earlier, I compared the benthic foraminifer faunas of Site 13 (Leg 3) with those from coeval sediments from Burdwood Bank (Macfadyen, 1933) and New Zealand (Scheibnerová, 1973a) and concluded that the only way to explain their Austral nature was to postulate a cold current approaching from the southwest and south along the eastern part of the Cretaceous South Atlantic Ocean, similar to the present Benguela Current; I also postulated a substantial northward shift of the African plate since the Late Cretaceous.

As far as the age of the benthic foraminifer faunas of Sites 363 and 364 is concerned, Site 363 represents the following stages: Cores 26 to 30 : middle-upper Albian (the nannoplankton age of this sequence is upper Albian); Core 31 (in part): early Albian: Cores 31 (in part) to 40: Aptian.

Benthic foraminifers of Site 364 show the following ages: Cores 24-25 upper Albian to ?lower Cenomanian (Lingulogavelinella frankei and Gavelinella oodnadattaensis); Cores 26 to 30: upper Albian; Cores 31-35: earlymiddle Albian; and Cores 38, 39, and 4l: upper Aptian.

\section{STRATIGRAPHIC SIGNIFICANCE OF APTIAN AND ALBIAN BENTHIC FORAMINIFERS}

Both Sites 363 and 364 penetrated Aptian and Albian sediments. The age determinations presented here are based on benthic foraminifer species as studied in the Great Australian Basin and elsewhere in the Austral Biogeoprovince (Scheibnerová, 1971-1976; Narayanan and Scheibnerová, 1975).

The Aptian age at Site 363 is based on the presence of the species Hergottella jonesi and Osangularia referred to the species $O$. occidentalis. Both species are known to occur in the Aptian, $H$. jonesi in the Great Australian Basin (Ludbrook, 1966; Scheibnerová, 1976) and $O$. occidentalis in California. I have seen specimens referable to $O$. occidentalis in Aptian sediments from South America sent to me for comparison by Dr. N. Malumian.

At Site 364, the Aptian age is based on the presense of $O$. occidentalis. This is supported by the absence of Albian age indicators (Lingulogavelinella frankei africana, L. frankei and typical L. albiensis, Orithostella indica, O. utaturensis, Anomalina indica, and some gavelinellas [ $G$. oodnadattaensis]) in both Sites 363 and 364 .

The early Albian age is based on the occurrence of Orithostella australiana at Site 363. At both sites, a middle-late Albian age is based on L. frankei africana, Orithostella indica, Anomalina indica, Charltonina australis, Tribrachia australiana, Osangularia utaturensis, Patellina africana, and Verneuilina howchini. The late Albian-early Cenomanian age is based on the occurrence of $L$. frankei, Gavelinella oodnadattaensis, Pseudopatellinella howchini, Gavelinella indica, Orithostella indica, Pseudolamarckina sp.. As in the Great Australian Basin and other parts of the Austral Biogeoprovince, it is difficult to place the Albian/Cenomanian boundary purely on the basis of benthic foraminifers.

\section{REMARKS ON THE OCCURRENCE AND SIGNIFICANCE OF SELECTED SPECIES}

\section{Orithostella indica}

Orithostella indica was originally described from middle-upper Albian deposits recovered by the DSDP in Leg 27 (Site 259) in the Indian Ocean (Scheibnerová, 1974a). Later it was recorded in upper Albian deposits in South (Peninsular) India by Narayanan and Scheibnerová (1975). I have also found this in upper Albian sediments of Melville Island and also in Western Australia (unpublished). The presence of $O$. indica at Sites 363 and 364 is very important from the paleogeographic point of view-it shows the existence of marine connections between the Indian and southern 
Atlantic oceans at that time. The stratigraphic distribution of $O$. indica in the South Atlantic is the same as in the Indian Ocean and on adjacent lands. It is a middle-upper Albian species. The scarcity of Orithostella in extremely shallow deposits supports my earlier conclusion based on DSDP samples from the Indian Ocean that Orithostella was a relatively deeper (outer shelf) element.

\section{Lingulogavelinella frankei Group}

Since the first discovery of Lingulogavelinella frankei in the Great Australian Basin, it has been recorded in its typical or allied forms in other parts of the Austral Biogeoprovince. In the DSDP samples from the Indian Ocean I found L. frankei in its typical form in Leg 26. In Albian samples of Leg 27 the typical form was almost non-existent, only a single specimen from Site 259 could be classified as $L$. frankei. This was interpreted either as a result of different ecological conditions (a relatively deeper environment, with Lingulogavelinella being a shallower element than other genera, such as Orithostella) or age differences (Albian deposits of Leg 27, Site 259, could probably be slightly older than those of Leg 26, Site 258, corresponding probably to the ?middle-late Albian). Similar reasons could have been responsible for the absence of $L$. frankei in its typical form in eastern South Africa; instead, here $L$. frankei africana occurred (Lambert and Scheibnerová, 1974). However, in Leg 40 samples, both L. frankei africana and typical $L$. frankei occur, as well as $L$. cf. albiensis. However, L. frankei occurs only in ?lower Cenomanian and upper Albian sediments in Site 364, whereas $L$. frankei africana occurs only in upper Albian and middle upper Albian sediments at Site 363. The reason for this can only be ecological in the case of the Albian sediments, but is both stratigraphic and ecological in the case of the Cenomanian deposits.

\section{Discorbis sp.}

Discorbis sp. was originally described from the Albian in the Great Australian Basin (Scheibnerová, $1972 \mathrm{a}, \mathrm{b})$, where it is a rare element in the New South Wales portion. It is definitely present in the material from South Australia studied by Ludbrook (1966). Subsequently, it was found in eastern South Africa (Zululand, described by Lambert and Scheibnerová, 1974), South America (personal communication by Malumian), and in the Indian Ocean (Scheibnerová, 1974 a, b) on both DSDP Legs 26 and 27. Although it occurs sporadically, it is one of the most widespread forms in the Austral Biogeoprovince. It seems to be a lower to upper Albian and Aptian species, as Malumian (Flores, et al., 1973) also found it to be in the Aptian of Argentina.

\section{Gavelinella oodnadattaensis}

This minute, but quite typical Gavelinella was described originally from the South Australian portion of the Great Australian Basin (Ludbrook, 1966). Haig (personal communication) found the species in the Queensland and Carpentaria portions of the Great Australian Basin in the uppermost parts of the marine Cretaceous profile, corresponding to late Albian-early Cenomanian.
It has not been recorded in either the New South Wales portion of the Great Australian Basin, or in DSDP samples from the Indian Ocean.

The occurrence of Gavelinella oodnadattaensis is interesting ecologically, because of the geographical distance between its Australian and South Atlantic occurrences. It seems to be of the same value stratigraphically, as it occurs in the same assemblage in both localities.

Osangularia utaturensis was originally described from Albian deposits on the Indian Peninsula by Sastri and Sastry (1966). Later it was found to occur in Albian sediments drilled in the Indian Ocean on DSDP Leg 27 (Scheibnerová, 1974a). Spirobolivina australis was also originally described from DSDP Leg 27 (Scheibnerová, 1974a).

\section{Other Characteristically Austral Species}

Among the species occurring in Leg 40 Cenomanian and Albian sediments, Anomalina indica, Pseudopatellinella howchini, Patellina africana Lambert and Scheibnerová, Patellinella australis Lambert and Scheibnerová, Gavelinella ex gr. intermedia (Berthelin), Pseudolamarckina sp., and Verneuilina howchini are the most important. They also occur in DSDP samples from the Indian Ocean, and in other parts of the Austral Biogeoprovince, most typically in the Great Australian Basin (Pseudolamarckina sp., Verneuilina howchini), the Indian Peninsula and Western Australia (Anomalina indica), and South Africa (Gavelinella ex gr. intermedia).

\section{BIOPROVINCIAL VALUE OF APTIAN, ALBIAN/?LOWER CENOMANIAN FORAMINIFERA AT SITES 363 AND 364}

As mentioned before, the benthic (and planktonic) foraminifer fauna contained in Sites 363 and 364 Aptian, Albian/?lower Cenomanian sediments is represented by genera and species known to occur in coeval sediments recovered in the Indian Ocean, Australia, South (Peninsular) India, South Africa, and many of them in South America. This means that this part of the Southern Atlanic Ocean, i.e., the Angola Basin, was under the direct influence of the Austral Biogeoprovince from the Aptian, Albian, to the ?lower Cenomanian at least. However, the Austral nature of the benthic foraminifer forms was still pronounced also in the Late Cretaceous (Scheibnerová, 1973a, b). The faunal affinity is extremely strong, with the occurrence of some forms which were originally regarded as endemic to the Great Australian Basin, for instance Hergottella jonesi (Howchin) (Ludbrook, 1966; Scheibnerová, 1976). It is also obvious that the Albian foraminifers of the Angola Basin include some elements in common with eastern South Africa (Zululand: Lambert and Scheibnerová, 1974a, b): most typically $L$. frankei africana. As mentioned above, Hergottella jonesi, regarded originally as endemic to the Great Australian Basin occurs in some samples from Site 363. This species, however, has not been found in either the DSDP samples from the Indian Ocean or on the mainland of eastern South Africa (Scheibnerová, $1974 a$, b). However, sediments from South Africa 
spanning the Aptian/Albian boundary have not been studied by anybody to my knowledge.

The conspicuously Austral nature of the benthic foraminifer faunas of the Angola basin shows that the water circulation pattern in the Aptian/Albian/?lower Cenomanian was not very different from that of the present day. The main feature of the marine transgression in the newly opened southern Atlantic Ocean was the influx of waters from the south. This was further emphasized by the lack of marine connections with the northern Atlantic waters. However, it is quite possible that some other northern marine connection existed perhaps through the Benue rift and the Sahara region. Evidence for the Late Cretaceous trans-Sahara transgression was given by Reyment (1969), and I discussed the foraminifer evidence for this elsewhere (Scheibnerová, 1973a, b). However, more evidence is needed to support the suggested Aptian/Albian transSahara marine connections.

\section{PALEOGEOGRAPHY OF THE LOWER CRETACEOUS TO CENOMANIAN SOUTHERN ATLANTIC SEAWAY}

The study of palynological data by Herngreen (1974) indicates a post-Cenomanian continental displacement. $\mathrm{He}$ stated that it was unlikely that a parallel evolution of floras on both sides of the South Atlantic Ocean, which began in the early Lower Cretaceous, would be the cause of the striking similarity between AlbianCenomanian floras of Brazil with those of coeval floras of present western equatorial Africa, Algeria, and Tunisia. A land connection between Brazil and the African continent, or at least a chain of closely spaced islands during the pre-Cenomanian time was proposed to account for the floral similarities. This conclusion, one of a land connection to the north during the Lower Cretaceous-Cenomanian, is strongly supported by the similarity of Lower Cretaceous-Aptian fresh-water ostracodes on corresponding sides of the Atlantic Ocean (see especially Krömmelbein, 1970). Krömmelbein showed that a high percentage of non-marine ostracode species had essentially the same stratigraphic order in the Brazilian "Wealden" of the BahiaSergipe basins and in the Cocobeach and postCocobeach Series in Gabon, Congo, and Angola.

Evaluation of Aptian evaporite deposits of Sergipe, Brazil, and Gabon, Congo, and Angola by Wardlaw and Nicholls (1972) showed striking similarities, e.g., tachyhydrite, a rare $\mathrm{CaCl}_{2}$-bearing mineral occurring abundantly in the deposits of the Congo region and in Sergipe. The trace elements $\mathrm{B}, \mathrm{F}, \mathrm{Br}, \mathrm{Ba}, \mathrm{Mn}, \mathrm{Tn}, \mathrm{Rb}$, $\mathrm{Cu}$, and $\mathrm{Tb}$ showed conspicuously similar average concentrations for both Africa and Brazil. Wardlaw and Nicholls (1972) concluded that the evaporites developed in a restricted seaway, closed to the North, during a transgression which marked an early phase (Aptian) of continental separation.

Marine benthonic foraminifer faunas of Sites 363 and 364 are conspicuous in that on one hand they contain many species in common with the areas of the Austral Biogeoprovince, and on the other, some species, especially those of Lingulogavelinella, show different distributions when the two sites are compared; whereas $L$. frankei in its typical form occurs in upper Albian/?lower Cenomanian deposits of Site 364, at Site
363 only $L$. frankei africana was identified. Foraminiferal faunas of both Sites 363 and 364 represent shallow-water assemblages that correlate directly with the nearshore assemblages of eastern South Africa (as described from Zululand by Lambert and Scheibnerová, 1974) and those of South Peninsular India (as described by Narayanan and Scheibnerová, 1975 ) and the Great Australian Basin (as studied by this present author). This fact is very important from the paleogeographic point of view, because it shows that in the Lower Cretaceous and early Upper Cretaceous at least at Sites 363 and 364 a shallow seaway existed which was closed to the north, but had free connections to the south with the Indian and South Pacific seaways of that time. However, the Lower CretaceousCenomanian equivalent of the southern Atlantic Ocean could have been wider to the south despite the comparatively shallow nature indicated by foraminiferal faunas at Sites 363 and 364.

There was apparently no obstacle to the distribution of these foraminifer species. Therefore the Walvis Ridge close to its present form either did not exist, or its existence was compensated for by the lack of northern connection. However, the former explanation is favored here, because the Late Cretaceous foraminifer faunas described from the north flank of Walvis Ridge (Todd, 1970) show much the same depth (not exceeding $2000 \mathrm{~m}$ ) as do those described from the present Sierra Leone Rise (Scheibnerová, 1973a, b).

\section{SYSTEMATICS}

\section{Anomalina indica Sastri and Sastry}

(Plate 4, Figures 19, 20)

1966 Anomalina indica Sastri and Sastry, p. 293, 294, pl. 19, fig. 10ac.

1974 Anomalina indica Sastri and Sastry, Scheibnerová, p. 714-715.

Description and remarks: Test free, of medium size, slightly asymmetrically planispiral, with one side slightly more involute than the other. The last whorl is composed of 10 chambers, which are slightly inflated initially, but with the last two chambers being strongly inflated. The periphery is subacute but becomes rounded in the 2-3 last-formed chambers. The sutures are slightly curved, distinct, moderately to strongly depressed. The umbilici are small, narrow, the less involute specimen may be filled with a small boss. The aperture is a distinct, narrow equatorial arch. The surface is smooth, and the wall calcareous and finely perforate.

The species is characteristic of DSDP samples from the Indian Ocean. This occurrence in the South Atlantic Ocean links that area paleogeographically with the Indian Peninsula, the Indian Ocean, and Australia.

Dimensions: diameter: $0.35-0.60 \mathrm{~mm}$; thickness: $0.17-0.30 \mathrm{~mm}$.

Charlotonina sp.

(Plate 4, Figures 11-13)

1973 Charltonina sp., Daily, p. 76-77, pl. 13, fig. 2a-c.

Description and remarks: Test free, small, trochospiral, biconvex, lobulate in side view. The periphery is acute. All chambers are visible on the dorsal side, whereas only the chambers of the final whorl are visible on the ventral side. The dorsal side is umbonate, with a layer of shell material covering the early chambers in adult specimens. The chambers are inflated on the umbilical side and increase gradually in size as added; the last whorl is composed of 5 to 7 chambers in the last whorl. The sutures on the dorsal side are curved or oblique and flush. The ventral sutures are almost radial, or slightly curved and depressed. The umbilicus is closed. The wall is calcareous, finely perforate, and smooth. The aperture forms a narrow slit that extends from the umbilicus nearly to the periphery, and continues up the apertural face parallel to the periphery.

Charltonina sp. will be described in a subsequent publication (Scheibnerová, in press) as Ch. australis sp. nov.

Dimensions: diameter: $0.20-0.35 \mathrm{~mm}$; thickness: $0.10-0.20 \mathrm{~mm}$. 
Discorbis sp.

(Plate 2, Figures 23, 24; Plate 2, Figures 1-5)

1972 Discorbis sp. Scheibnerová, p. 213, pl. 1, fig. 1a-c; pl. 2, fig. 1a-b.

1974 Discorbis sp. Lambert and Scheibnerová, p. 82, pl. 1, fig. 6, 7, text-figure 17

Description and remarks: Test free, trochospiral, calcareous, planoconvex, or concavo-convex, flat or concave on the umbilical side. The primary aperture is an interiomarginal extra-umbilical arch; very characteristic are the secondary sutural openings on opposite sides of each chamber flap. These remain open as successive chambers are formed. In some very well preserved specimens the sutural openings are clearly visible (see Scheibnerová, 1972b, pl. 1, fig. la-c; pl. 2, fig. la-b) and extend along the proximal side of each radial umbilical flap and are connected through a cavity beneath the flaps to the interior of the chambers.

Dimensions: maximum diameter: $0.25-0.55 \mathrm{~mm}$; minimum diameter: $0.25-0.40 \mathrm{~mm}$; thickness: $0.15-0.25 \mathrm{~mm}$.

\section{Gavelinella ex gr. intermedia (Berthelin)}

(Plate 2, Figures 12-14)

1880 Anomalina intermedia Berthelin, p. 67-68, pl. 4, fig. 14a-c.

1965 Gavelinella (Berthelina) intermedia, Malapris, p. 138-139, pl. 1, fig. $2-4$, (non-fig. 1, 5, 7); pl. 2, fig. 2-4 (non-fig. 2, 5, 7).

1966 Gavelinella intermedia (Berthelin, 1880), Michael, p. 432, 434, pl. 50, fig. 4-13 (cum syn).

1972 Gavelinella (Berthelina) intermedia (Berthelin), Gawor-Biedowa, p. 120-121, pl. 15, fig. 7-9 (a-c), fig. 12.

Description and remarks: Test free, calcareous, planispiral, nearly bilaterally symmetrical, round in outline, semi-involute, with chambers of $1-1 / 2$ whorls visible. The dorsal side is more convex than the ventral. The periphery is narrowly rounded. The last whorl is composed of $9-12$ chambers. The sutures are slightly curved on both sides of the test and become distinct between the ultimate chambers of the last whorl. The umbilical depression on the spiral side is often filled with imperforate secondary calcite, that sometimes forms a knob. The apertural part of the test is involute and bears a slit-like interiomarginal-equatorial aperture. The aperture is covered by a wide imperforate lip that extends to the ventral side under the imperforate flaps of the final chambers.

Dimensions: maximum diameter: $0.25-0.45 \mathrm{~mm}$; minimum diameter: $0.20-0.35 \mathrm{~mm}$; thickness: $0.15-0.21 \mathrm{~mm}$.

\section{Gavelinella oodnadattaensis Ludbrook}

1966 Gavelinella oodnadattaensis Ludbrook, p. 141, pl. 12, fig. 17, 18.

Description and remarks: Test free, small, trochospiral, very slightly convex spirally, compressed in transverse section. The periphery is slightly lobulate, especially in the later part of the final whorl. All the chambers of the 2-1/2 whorls are visible on the spiral side; only those of the last whorl are visible on the umbilical side. The chamber number in the last whorl is 8 or 9 . The chambers are rather higher than broad, moderately inflated on the umbilical side, and increase gradually in size as added. The sutures are distinct, depressed, gently curved; the wall is calcareous, finely perforate, smoothly finished. The aperture is peripheroventral forming a lowinteriomarginal slit extending from the peripheral margin to the umbilicus beneath the umbilical chamber flaps. $\mathrm{mm}$.

Dimensions: longer diameter: $0.15-0.25 \mathrm{~mm}$; thickness: $0.07-0.10$

\section{Globorotalites michelinianus (d'Orbigny)}

(Plate 4, Figures 2-4)

1968 Globorotalites michelinianus (d’Orbigny), Sliter, p. 119, pl. 22, fig. 1 (cum syn.).

Description and remarks: Test free, trochospiral, planoconvex, with a flat spiral side and a slightly convex umbilical side with a prominent pseudoumbilicus. The periphery is acutely carinate. The final whorl is composed of 7 or 8 chambers increasing gradually in size. Sutures are oblique, limbate, and flush on the spiral side, and slightly curved and becoming somewhat depressed on the umbilical side. The wall is calcareous, granular in structure, and finally perforate, with a smooth surface. The aperture is an interiomarginal slit at the base of the final chamber.

Dimensions: diameter: $0.20-0.50 \mathrm{~mm}$; thickness: $0.20-0.30 \mathrm{~mm}$.

\section{Hergotella jonesi (Howchin)}

(Plate 4, Figures 5-10)

1895 Patellina jonesi Howchin, p. 199, pl. 10, fig. 9, 11

1966 Hergotella jonesi (Howchin), Ludbrook, p. 135-136, pl. 13, fig. 19-22, 27, 28.

Description and remarks: Test free, conical, as high as wide, circular in outline with rounded periphery; dorsal side convex and ventral side flat or concave. The test consists of a series of chambers of more than one whorl. Sutures flush, visible in translucent specimens as a row of coarse pores; aperture a small arch near the umbilicus with a long and narrow apertural flap; median septa are pillar-like. $\mathrm{mm}$.

Dimensions: height: $0.25-0.35 \mathrm{~mm}$; maximum diameter: $0.25-0.30$

Lingulogavelinella frankei africana Lambert and Scheibnerová (Plate 2, Figures 15-19; Plate 3, Figures 1-4)

1974 Lingulogavelinella frankei africana Lambert and Scheibnerová, p. 84, pl. 1 , fig. 8 .

Description and remarks: Test free, small, strongly involute with chambers that are inflated on the ventral side and flat on the dorsal side. The chamber number in the last whorl is 5 to 7 . The periphery is subacute, lobate; the sutures are distinct, depressed, and radial. The aperture is periphero-dorsal with a distinct asterisk of perforate chamber wall extensions covering the dorsal part of the aperture. The wall is calcareous, perforated by sparse, medium to large pores and is smooth.

The specimens differ from Lingulogavelinella frankei frankei (Bykova) in showing a greater degree of variability in chamber form and a distinct tendency to form a less convex dorsal side and a more acute and lobate periphery.

Dimensions: maximum diameter: $0.20-0.35 \mathrm{~mm}$; minimum diameter: $0.19-9.25 \mathrm{~mm}$; thickness: $0.10-0.15 \mathrm{~mm}$.

\section{Orithostella australiana Scheibnerová}

(Plate 3, Figures 7, 8, 12, 13)

1972 Orithostella australiana Scheibnerová, p. 214-215, pl. 1, fig. 3, text-fig. 7a-c.

1976 Orithostella australiana Scheibnerová, p. 95-96, pl. 68, fig. 4-8.

Description and remarks: Test of medium size, trochospiral and plano-convex with the spiral side flat or very slightly inflated, and the ventral side strongly inflated. The last whorl is composed of 7 to 9 chambers. The periphery is narrowly rounded and the "imperforate keel" observed by Eicher and Worstell (1970) in the type species viriola was observed in a few specimens only. The chambers are convex ventrally and flat or slightly convex dorsally. The aperture forms a peripheral arch of slit extending dorsally and is covered by more or less distinct perforate extensions of the chamber walls. The wall is calcareous, smooth and sparsely perforated.

Dimensions: maximum diameter: $0.50-0.65 \mathrm{~mm}$; minimum diameter: $0.50-0.56 \mathrm{~mm}$; thickness: $0.30-0.32 \mathrm{~mm}$.

Orithostella indica Scheibnerová

(Plate 3, Figures 9-11, 14-16)

1974 Orithostella indica Scheibnerová, p. 715, pl. 7, fig. 4, 8-13; pl. 8, fig. 1-9; pl. 11, fig. 9a-c.

1975 Orithostella indica Scheibnerová, Narayanan and Scheibnerová,

p. 29 , pl. 1 , fig. 5 .

Description and remarks: Test free, of medium to small size, calcareous, low trochospiral, involute, with slightly less involute umbilical (aboral) side and involute dorsal (oral) side. The periphery is narrow, subangular, sometimes with a nonperforate keel. Only the chambers of the last whorl are visible on both sides. The last whorl is composed of 7 to 9 flat or slightly inflated chambers. Those of the umbilical side are more convex, however, but less than in the type species $O$. viriola. The aperture is periphero-dorsal and its dorsal part is covered by large tongue-like imperforate extensions of the chamber wall along one third of the length of the sutures between the chambers. The peripheral part of the aperture is bordered by a rim on some specimens.

\section{Orithostella viriola Eicher and Worstell}

(Plate 3, Figures 17-20)

1970 Orithostella viriola Eicher and Worstell, p. 295, pl. 6, fig. 6a-c, $7 a-b, 10 a-c$. 
Description and remarks: Test free, trochospiral, plano-convex, 79 chambers in the last whorl, with a flat dorsal side and a strongly convex ventral side. Some specimens have a small, central boss. The periphery is very narrowly rounded, often with a thick imperforate keel. The chambers increase rapidly in height and thickness, are flat dorsally, inflated ventrally, with the steeply sloping sides often concave in edge view. The sutures are depressed on the ventral side and strongly curved on both sides. The wall is calcareous, granular in structure, and perforate on both sides. The aperture is peripherodorsal. The dorsal part of the aperture forms an asterisk-like pattern of chamber wall extensions covered by an imperforate secondary calcite layer.

Dimensions: maximum diameter: $0.24-0.45 \mathrm{~mm}$; thickness: $0.15-$ $0.30 \mathrm{~mm}$.

\section{Osangularia occidentalis Dailey, 1970}

(Plate 4, Figures 17, 18)

1970 Osangularia occidentalis Dailey, p. 110, pl. 14, fig. 3, 4.

Description and remarks: Test free, low trochospiral, involute, compressed, subcircular, lenticular, being gently convex dorsally, flat to gently convex ventrally. The periphery is sharply rounded to acute. The chambers are flat, usually $10-11$ in the last whorl, increasing gradually in size as added. The sutures are distinct, strongly curved, sometimes slightly sigmoidal on ventral side, oblique, limbate, and coalescing centrally on the ventral side forming a small button of clear shell material. The wall is calcareous, finely perforate and smooth. The aperture is V-shaped forming an interiomarginal slit between the umbilicus and periphery, with an oblique extension onto the apertural face. The present specimens appear practically identical with the types described originally by Dailey (1970) from California. In California, $O$. occidentalis occurs in the upper Aptian-lower Albian, whereas in Site 364 the species is restricted to samples of Aptian age.

Dimensions: maximum diameter: $0.20-0.65 \mathrm{~mm}$; minimum diameter: $0.17-0.60 \mathrm{~mm}$; thickness: $0.10-0.30 \mathrm{~mm}$.

\section{Patellinella australis Lambert and Scheibnerová} (Plate 4, Figures 14, 15)

1974 Patellinella australis Lambert and Scheibnerová, p. 82, pl. 3, fig. 5 ; text-fig. 12.

Description and remarks: Test free, conical, trochoid, planoconvex. The earliest whorl is usually composed of 3 chambers, and as a rule broken; later there are only 2 chambers per whorl. All whorls are visible on the dorsal side; only the final 2 chambers are visible on the ventral side. The wall is calcareous, very finely perforate and radial in structure. The aperture is a ventral broad arch opening into the umbilicus. The last 2 chambers are flatter and broader (sometimes lobulate) than the previous chambers.

The species was originally described from the middle/upper Albian of Zululand in South Africa. These specimens were interpreted by Lambert and Scheibnerová (1974) as having been deposited in shallow-water, inner-shelf sediments.

Dimensions: diameter: $0.25-0.35 \mathrm{~mm}$; height: $0.20-0.30 \mathrm{~mm}$; thickness: $0.10-0.18 \mathrm{~mm}$.

\section{?Serovaina $\mathbf{s p}$}

(Plate 2, Figures 9, 10)

1957 Gyroidina globosa (Hagenow) var. orbicella Bandy, p. 505, pl. 74 , fig. 2 .

1968 Serovaina orbicella (Bandy), Sliter, p. 92, pl. 13, fig. 12.

Description and remarks: Test free, trochospiral, with the spiral side partially evolute and the umbilical side completely involute. The last whorl is composed of 6 to 8 inflated chambers increasing rapidly in size. The sutures are distinct, radial, and depressed. The periphery is broadly rounded. The wall is calcareous, finely perforate, radial in structure, monolamellar, and smooth. The aperture forms a low interiomarginal slit at the base of a high apertural face and extends from near the periphery to the umbilicus, often with a small lip.

Very similar forms were described from the Great Australian Basin by Scheibnerová (1976), who also discussed their taxonomic position.

\section{ACKNOWLEDGMENT}

Permission to publish this report was given by the Undersecretary of the New South Wales Mines Department.

\section{REFERENCES}

Byrnes, J., Morgan, R., and Scheibnerová, V., 1975. Recent evidence for the age of Great Australian Basin Cretaceous sediments in New South Wales: GS N.S.W., Quart. Notes 18 , p. 2-13.

Calvez, Le, Y., Klasz, de, I., and Brun, L., 1971. Qualques foraminiferes de l'Afrique occidentale: Rev. Espan. Micropal., v. 3, p. 305-326.

Crespin, T., 1944. Some Lower Cretaceous foraminifera from bores in the Great Artesian Basin, northern New South Wales: J. Proc. Roy. Soc. N.S.W., v. 79, p. 17-24.

1953. Lower Cretaceous foraminifera from the Great Artesian Basin, Australia: Contrib. Cushman Found. Foram. Res., v. 4, p. 26-36.

1956. Distribution of Lower Cretaceous foraminifera in bores in the Great Artesian Basin, northern New South Wales: J. Proc. Roy. Soc. N.S.W., v. 89 , p. $78-84$.

1963. Lower Cretaceous arenaceous foraminifera of Australia: Bull. Bur. Min. Res. Geol. Geophys. Aust., v. 66, p. $1-110$.

Flores, M.A., Malumian, N., Masiuk, V., and Riggi, J.C., 1973. Estratigrafia cretacica del subsuelo de Tierra del Fuego: Rev. Asoc. Geol. Argentina, v. 28, p. 407-437.

Herb, R., 1974. Cretaceous planktonic foraminifera from the Eastern Indian Ocean. In Heirtzler, J.R., Veevers, J.J., et al., Initial Reports of the Deep Sea Drilling Project, Volume 27: Washington (U.S. Government Printing Office), p. 745-755.

Herngreen, G.F.W., 1974. Middle Cretaceous palynomorphs from northeastern Brazil: Sci. Geol. Bull., v. 27, p. 101-116.

Krömmelbein, K., 1970. Non-marine Cretaceous ostracodes and their importance for the thesis of "Gondwanaland": Proc. Pap. I.U.G.S., Sec. Gondw. Symp., South Africa, p. 617-619.

Lambert, G. and Scheibnerova, V., 1974. Albian foraminifera of Zululand (South Africa) and Great Artesian Basin (Australia): Micropaleontology, v. 20, p. 76-96.

Ludbrook, N. H., 1966. Cretaceous biostratigraphy of the Great Artesian Basin, in South Australia: Bull. Geol. Surv. S. Aust., v. 40, p. 1-223.

Macfadyen, W. A., 1933. Fossil foraminifera from the Burdwood Bank and their geological significance: Discovery Rep., v. 7, p. 1-16.

Narayanan, V. and Scheibnerová, V., 1975. Lingulogavelinella and Orithostella (Foraminifera) from the Utatur group of the Trichinopoly Cretaceous, South (Peninsular) Indian: Rev. Espanola Micropal., v. 7, p. 25-36.

Reyment, R. A., 1969. Ammonite biostratigraphy, continental drift and oscillatory transgressions: Nature, v. 224 , p. $137-140$.

Sastry, N.V.A. and Sastri, V.V., 1966. Foraminifera from the Utatur Stage of the Cretaceous formations of Trichinopoly district, Madras: Rec. Geol. Surv. India, v. 94 , p. $277-296,17-21$.

Scheibnerová, V., 1971a. Foraminifera and their Mesozoic Biogeoprovinces: Rec. Geol. Surv. N.S.W., v. 3, p. 135174.

1971. Lingulogavelinella (foraminifera) in the Cretaceous of the Great Artesian Basin, Australia: Micropaleontology, v. 17, p. 109-116.

1972a. Bilingulogavelinella australis n. gen. n. sp. (Foraminifera) from the marine Cretaceous of the Great Artesian Basin, Australia: J. Foram. Res., v. 1, p. 122-125. 1972b. Some interesting foraminifera from the Cretaceous of the Great Artesian Basin, Australia: Micropaleontology, v. 18, p. 212-222. 
1973a. Non tropical Cretaceous foraminifera from the Atlantic deep sea cores and their implications for continental drift and paleooceanography of the southern Atlantic Ocean: Rec. Geol. Surv. N.S.W., v. 15, p. 19-46. 1973b. Possible Cretaceous migration routes for Austral foraminifera: Geol. Surv. N.S.W. Quart. Notes, v. 12 , p. $7-18$.

1974a. Aptian-Albian benthonic foraminifera from DSDP Leg 27, Sites 259, 260, and 263, In Eastern Atlantic Ocean. In Heirtzler, J.R., Veevers, J.J., et al., Initial Reports of the Deep Sea Drilling Project, Volume 27: Washington (U.S. Government Printing Office), p. $697-$ 742.

1974b. The ecology of Scutuloris and other important genera from the early Cretaceous of the Great Artesian Basin (Australia): Rev. Espanola Micropal., v. 6, p. $229-255$.
1975. Correlation of foraminiferal and palynological datum horizons, zones and subzones in the Cretaceous of the Great Australian Basin. Geol. Surv. N.S.W. Quart. Notes 21, p. 8-17.

1976. Cretaceous foraminifera of the Great Australian Basin: Mem. Geol. Surv. N.S.W., no. 17, p. 1277.

in press. Cretaceous foraminiferal biostratigraphy of the Great Australian Basin: Rec. Geol. Surv. N.S.W.

Todd, R., 1970. Maestrichtian (Late Cretaceous) Foraminifera from a deep-sea core off southwestern Africa: Rev. Espanola Micropal., v. 2, p. 131-154.

Wardlaw, N. C. and Nicolls, G. D., 1972. Cretaceous evaporites of Brazil and West Africa and their bearing on the theory of continental separation: 24th IGC mtg., Sect. 6, p. 43-55. 


\section{PLATE 1}

Figure 1 Ammodiscus sp.; specimen no. MMMC 01086; Section 363-30-5; $\times 135$.

Figure 2 Ammodiscus sp.; specimen no. MMMC 01086; Section 363-30-5; $\times 180$.

Figure 3 Haplophragmoides sp.; Sample 364-4104, 28-30 cm; $\times 225$ (specimen lost).

Figure 4 Textularia sp.; specimen no. MMMC 01061; Sample 363-26-1, 99-101 cm; $\times 135$.

Figure 5 Spiroplectammina; specimen no. MMMC 01012; Section 363-38-2 (top); $\times 108$.

Figure $6 \quad$ Verneuilina howchini Crespin; specimen no. MMMC 01078; Section 363-30-5 (top); $\times 72$.

Figure $7 \quad$ Verneuilina howchini Crespin; specimen no. MMMC 01077; Section 363-30-5 (top); $\times 135$.

Figure $8 \quad$ Gaudryina sp.; specimen no. MMMC 01097; Sample 364-24, CC; $\times 180$.

Figure 9 Gaudryina sp.; specimen no. MMMC 01094; Sample 364-24, CC; $\times 99$.

Figure $10 \quad$ Migros sp.; specimen no. MMMC 01010; Section 363-38-2 (top); $\times 135$.

Figure 11 Dorothia sp.; specimen no. MMMC 017071; Sample 363-26-1, 99-101 cm; $\times 108$.

Figure 12 Clavulina gabonica Le Calvez, de Klasz and Brun; specimen no. MMMC 01011; Section 363-38-2 (top); $\times 90$.

Figure 13 Clavulina gabonica; specimen no. MMMC 01069; Section 363-26-1; $\times 72$.

Figure 14 Dorothia sp.; specimen no. MMMC 01079; Section 363-30-5 (top); $\times 135$.

Figure 15 Tribrachia sp.; specimen no. MMMC 01073; Sample 363-26-1, 99-101 cm; $\times 135$.

Figure 16 Tribrachia australiana Ludbrook; specimen no. MMMC 01072; Sample 363-26-1, 99$101 \mathrm{~cm} ; \times 113$.

Figure 17 Lenticulina sp.; specimen no. MMMC 01083; Section 363-30-5 (top); $\times 135$.

Figure 18 Lenticulina sp; specimen no. MMMC 01093; Sample 363-26-1, 99-101 cm; $\times 99$.

Figure 19 Citharina sp.; specimen no. MMMC 01074; Sample 363-26-1, 99-101 cm; $\times 54$.

Figure $20 \quad$ Frondicularia sp.; specimen no. MMMC 1058; Sample 363-2601, 99-101 cm; $\times 54$.

Figure $21 \quad$ Frondicularia sp.; specimen no. MMMC 01090; Sample 363-26-1, 99-101 cm; $\times 72$.

Figure 22 Pyrulina cylindroides; specimen no. MMMC 01085; Section 363-30-5 (top); $\times 90$.

Figure 23 Discorbis (?Valvulineria) sp.; specimen no. 01100; Sample 364-24, CC; $\times 154$.

Figure 24 Discorbis (?Valvulineria) sp.; specimen no. 01098; Sample 364-24, CC; $\times 135$ :

Figure 25 Pleurostomella obtusa Berthelin; specimen lost; Sample 364-40-41-4, 28-30 cm; $\times 90$.

Figure $26 \quad$ Pleurostomella obtusa; specimen no. MMMC 01107; Sample 364-40-41-4, 28-30 cm; $\times 90$. 
Plate 1

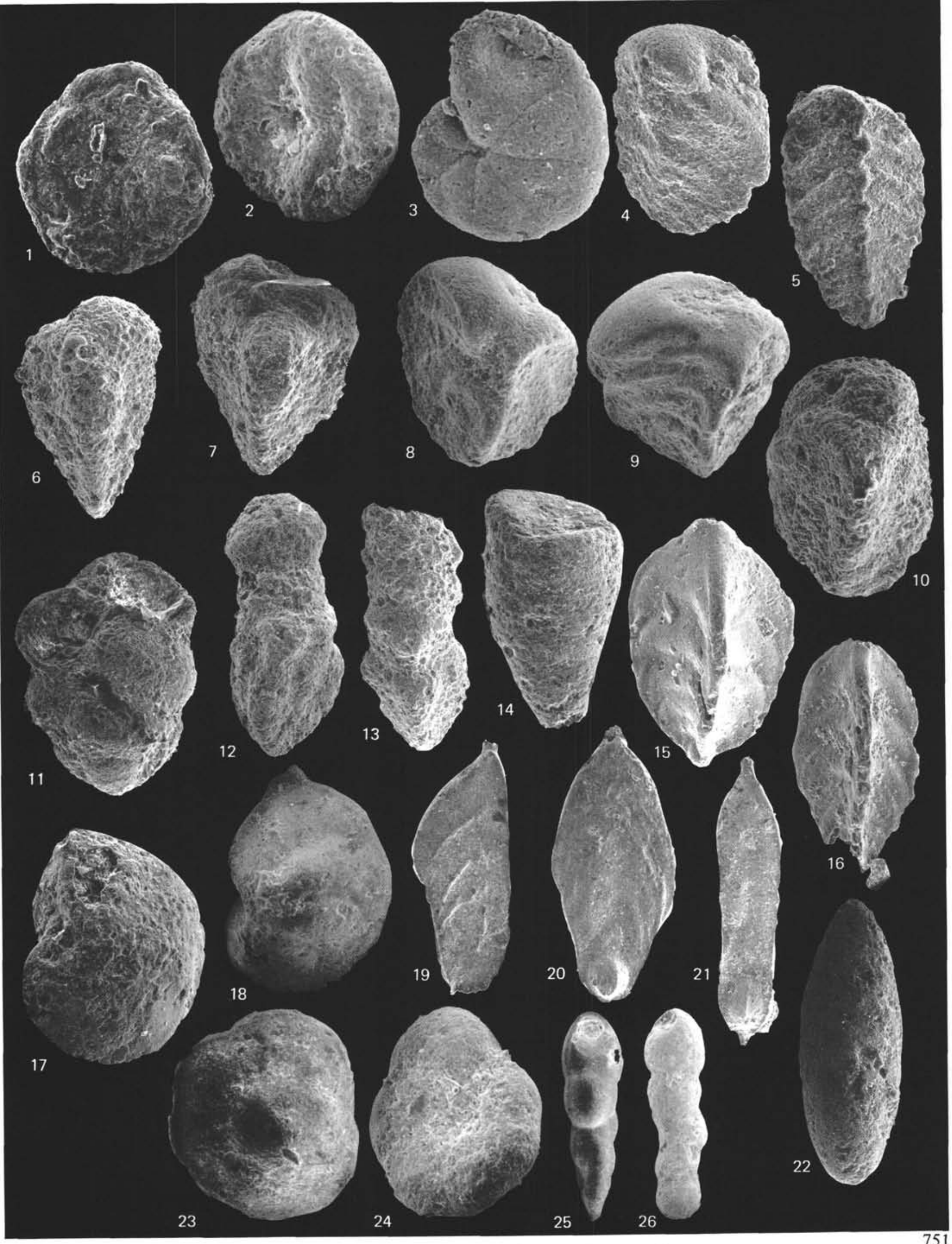




\section{PLATE 2}

Figure 1 Discorbis sp. spiral side; specimen no. MMMC 01068; Sample 36326-1, 99-101 cm; $\times 136$.

Figure 2 Discorbis sp. spiral side; specimen no. MMMC 01000; Sample 36326-1, 99-101 cm; $\times 110$.

Figure 3 Discorbis sp. umbilical side (the same specimen as above); $\times 136$.

Figure 4 Discorbis sp. (juv.); specimen no. MMMC 01006; Section 363-38-2 (top); $\times 159$.

Figure 5 Discorbis sp. (juv.); specimen no. MMMC 01006; Section 363-38-2 (top); $\times 182$.

Figure 6 Osangularia occidentalis Dailey; specimen no. MMMC 01008; Section 363-38-2 (top); both $\times 146$.

Figure 7 Osangularia occidentalis Dailey; specimen no. MMMC 01008; Section 363-38-2 (top); both $\times 146$.

Figure $8 \quad$ Gyroidinoides primitiva Hofker; specimen no. MMMC 01087; Section 363-30-5 (top); $\times 182$.

Figure 9 ?Serovaina sp.; specimen no. MMMC 01014; Section 363-38-2 (top); $\times 155$.

Figure 10 ?Serovaina sp.; specimen no. MMMC 01013; Section 363-27-2 (top); $\times 155$.

Figure 11 Gyroidinoides sp.; specimen no. MMMC 01060; Sample 363-26-1, 99-101 cm; $\times 136$.

Figure 12 Gavelinella ex gr. intermedia Berthelin; specimen no. MMMC 01084; Section 363-30-5 (top); $\times 109$.

Figure 13 Gavelinella ex gr. intermedia Berthelin; specimen no. MMMC 01088; Section 363-30-5 (top); $\times 100$.

Figure $14 \quad$ Gavelinella ex gr. intermedia Berthelin; specimen no. 01082; Section 363-30-5 (top); $\times 136$.

Figure 15 Lingulogavelinella frankei africana Lambert and Scheibnerová dorsal (oral) side; specimen no. MMMC 00999; Sample 40-363-26$1,99-101 \mathrm{~cm} ; \times 109$.

Figure $16 \quad$ Lingulogavelinella frankei africana; ventral (aboral) side; $\times 136$.

Figure 17 Lingulogavelinella frankei africana Lambert and Scheibnerová, ventral (aboral) side; specimen no. MMMC 00998; Sample 363-26$1,99-101 \mathrm{~cm} ; \times 100$.

Figure 18 Lingulogavelinella frankei africana Lambert and Scheibnerová, detail of the specimen above; Sample 363-26-1, 99-101 cm; $\times 296$.

Figure 19 Lingulogavelinella frankei africana Lambert and Scheibnerová, dorsal (oral) side; specimen no. MMMC 00998; Sample 363-26-1, 99-101 cm; $\times 136$. 
PLATE 2

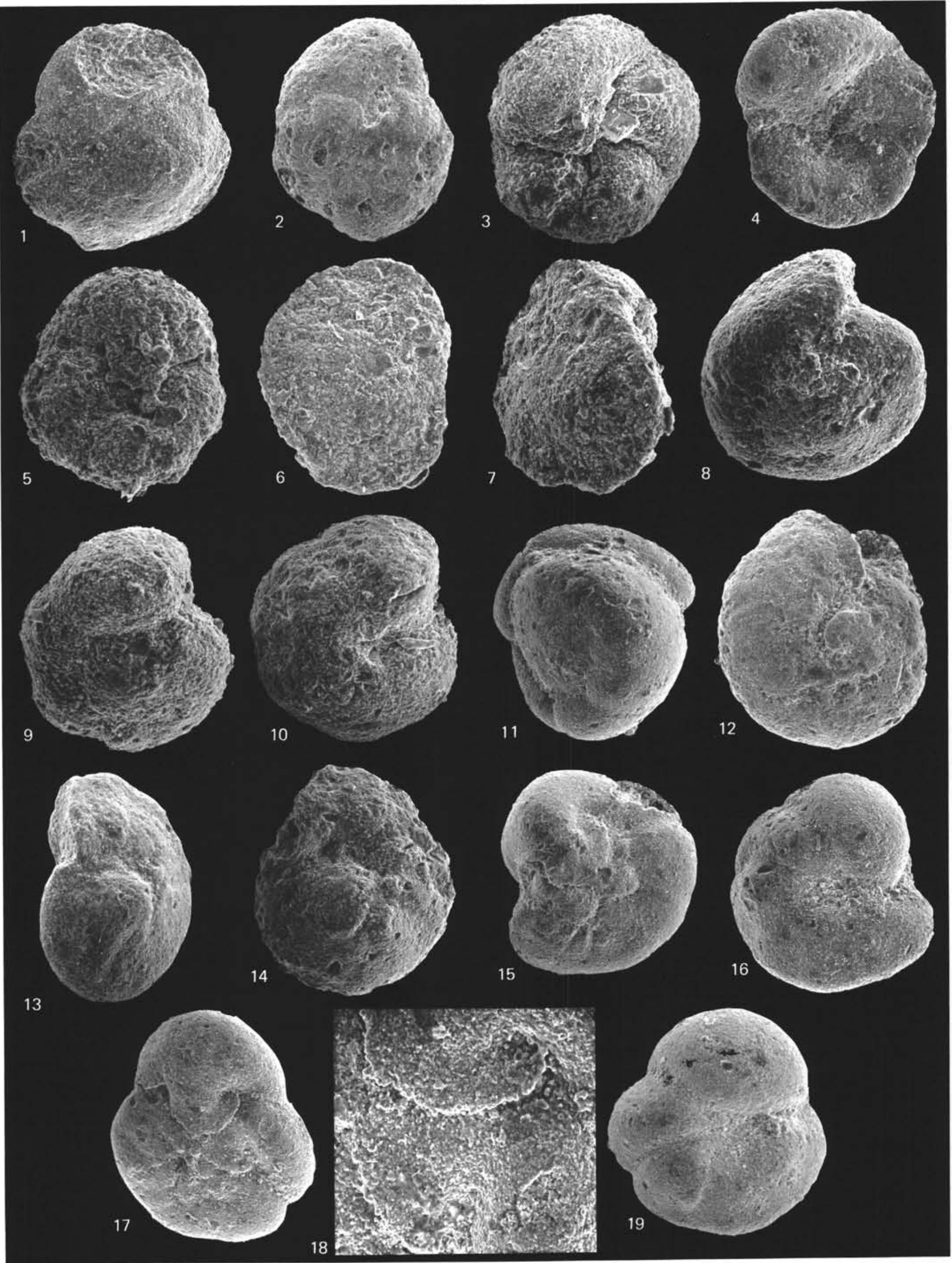




\section{PLATE 3}

Figure 1 Lingulogavelinella frankei africana Lambert and Scheibnerová; specimen no. MMMC 01066; Sample 363-26-1, 99-101 cm; ×138.

Figure 2 Lingulogavelinella frankei africana Lambert and Scheibnerová; Umzinene R. 13f, $\times 115$.

Figure 3 Lingulogavelinella frankei africana Lambert and Scheibnerová; Umzinene R. 13f, $\times 184$.

Figure 4 Lingulogavelinella frankei africana Lambert and Scheibnerová; Umzinene R. 13f, $\times 115$.

Figure 5 Lingulogavelinella frankei (Bykova); specimen no. MMMC 01056; Sample 364-24, CC; $\times 322$.

Figure 6 Lingulogavelinella frankei (Bykova); specimen no. MMMC 01056; Sample 364-24, CC; ×322.

Figure 7 Orithostella australiana; specimen no. MMMC 01080; Section 363-30-5 (top); $\times 138$.

Figure $8 \quad$ O. australiana; specimen no. MMMC 01001; Sample $363-30-1,38-40 \mathrm{~cm} ; \times 138$. Also as $12(8)$.

Figure $9 \quad$ Orithostella indica; specimen no. MMMC 00997; Sample 363-26-1, 99-101 cm; $\times 110$.

Figure $10 \quad O$. indica Scheibnerová; the same specimen as above; $\times 110$.

Figure $11 \quad$ Details of Figure 10; $\times 368.997$

Figure 12 Orithostella australiana Scheibnerová; specimen no. MMC 01001; Section 363-30-5 (top); $\times 110$. Also as 7 .

Figure 13 Orithostella australiana Scheibnerová; the same specimen as above; $\times 101$.

Figure $14 \quad O$. indica Scheibnerová; specimen no. MMMC 01059; Sample 363-26-1, 99-101 cm; $\times 138$.

Figure $15 \quad$ Orithostella indica; specimen no. MMMC 01059; Sample 363-26-1, 99-101 cm; $\times 138$.

Figure 16 Orithostella indica; specimen no. MMMC 01064; Sample 363-26-1, 09-101 cm; $\times 138$.

Figure 17 Orithostella viriola Eicher and Worstell; specimen no. MMMC 01091; Sample 363-26-1, 99-101 cm; $\times 138$.

Figure 18 Orithostella viriola Eicher and Worstell, ventral side; specimen no. MMMC 00996; Sample 363-261, 99-101 cm; $\times 138$.

Figure 19 Orithostella viriola Eicher and Worstell (n. sp.?); specimen no. 00996 , dorsal side; $\times 138$.

Figure 20 Orithostella viriola Eicher and Worstell; specimen no. 01057; dorsal side; Sample 363-26-1, 99-101 $\mathrm{cm} ; \times 138$. 
PLATE 3

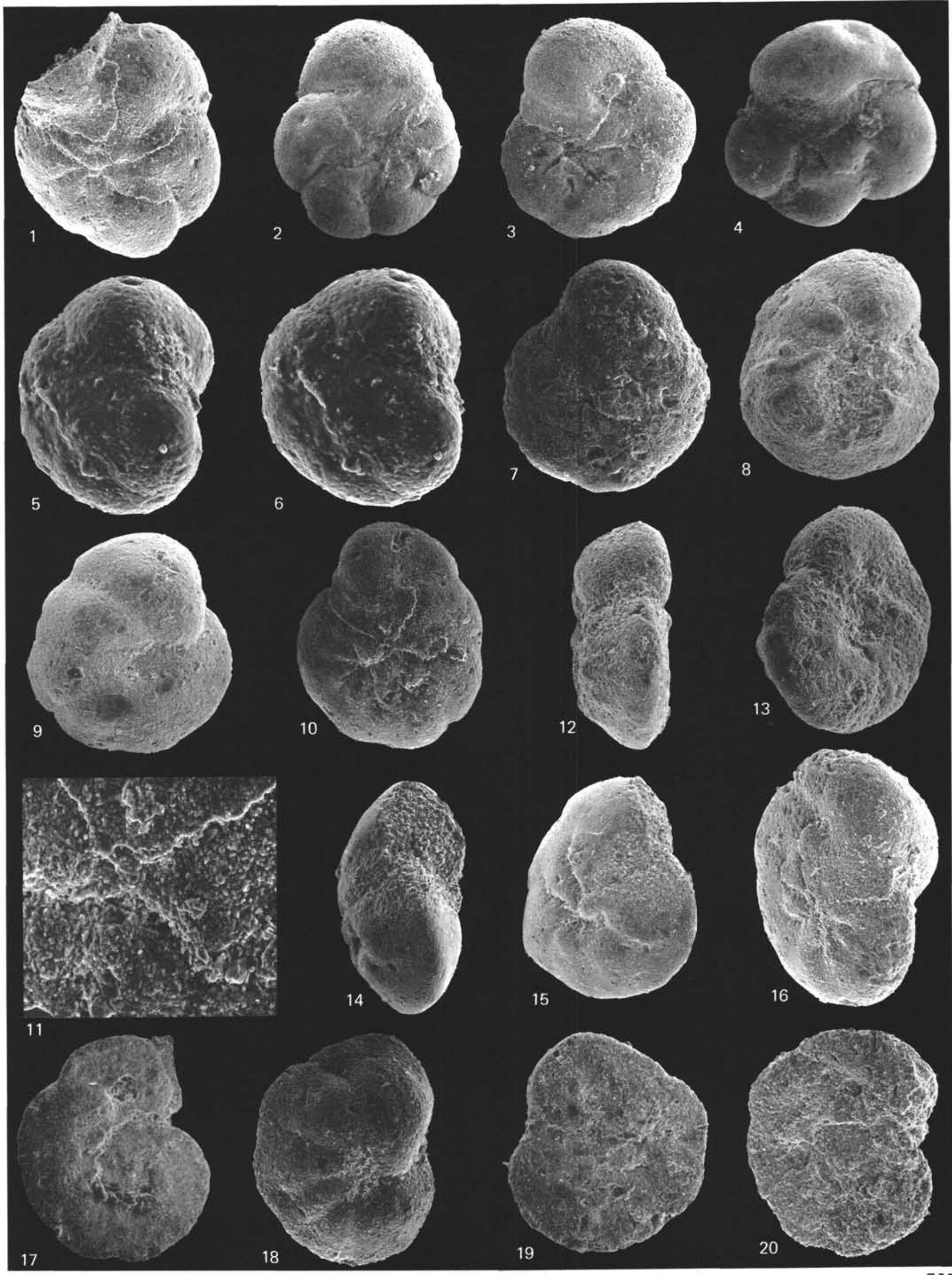


PLATE 4

Figure 1

Figure 2

Figure 3

Figure 4

Figure 5

Figure 6

Figure 7

Figure 8

Figure 9

Figure 10

Figure 11

Figure 12

Figure 13

Figure 14

Figure 15

Figure 16

Figure 17

Figure 18

Figure 19

Figure 20
Globorotalites sp.; specimen no. 01001; Section 363-38-2 (top); $\times 155$.

Globorotalites michelinianus (d'Orb.); specimen no. MMMC 01081; Section 363-30-1 (top); $\times 137$.

Globorotalites michelianus; specimen no. MMMC 01067; Sample 363-26-1, 99-101 cm; $\times 82$.

Globorotalites michelianus; specimen no. MMMC 01063; Sample 363-26-1, 99-101 cm; $\times 64$.

Hergottella jonesi (Howchin); specimen no. MMMC 01004; Section 363-38-2 (top); $\times 182$.

Hergottella jonesi (Howchin); specimen no. MMMC 00995; Section 363-30-5 (top); $\times 137$.

Detail of the same specimen as above; $\times 137$.

Hergottella jonesi (Howchin); specimen no. MMMC 00995; spiral side of the same specimen as Figure 10; $\times 137$.

Hergotella jonesi (Howchin); specimen no. MMMC 263-31-4; Sample 363-31-4, 119-121 cm; $\times 182$.

Hergottella jonesi (Howchin); specimen no. 01076; Sample 363-31-4, 119-121 cm; X182.

Charltonina sp.; specimen no. MMMC 01002; Section 363-27-2 (top); $\times 228$.

Charltonina sp.; specimen no. MMMC 01002; Section 363-27-2 (top); $\times 282$.

Charltonina sp.; specimen no. MMMC 01009; Section 363-17-2 (top); $\times 228$.

Patellinella australis Lambert and Scheibnerová; Sample 363-26-1, 99-101 cm; $\times 109$.

Patellinella australis Lambert and Scheibnerová; specimen no. MMMC 00000; Section 364-41-4, $28-30 \mathrm{~cm} ; \times 200$.

Osangularia australis Lambert and Scheibnerová; specimen no. MMMC 00000; Sample 364-41-4, $28-30 \mathrm{~cm} ; \times 182$.

Osangularia occidentalis Dailey; specimen no. MMMC 01 106; Sample 364-41-4, 28-30 cm; ×146.

Osangularia occidentalis Dailey; specimen no. MMMC 01105; Sample 363-26-1, 99-101 cm; $\times 100$.

Anomalina indica (Sastri and Sastry); specimen no. MMMC 01093; Sample 363-25-1, 99-101 cm; $\times 100$.

Anomalina indica; specimen no. MMMC 01096; Sample 363-26-1, 99-101 cm; $\times 82$. 


\section{PLATE 4}

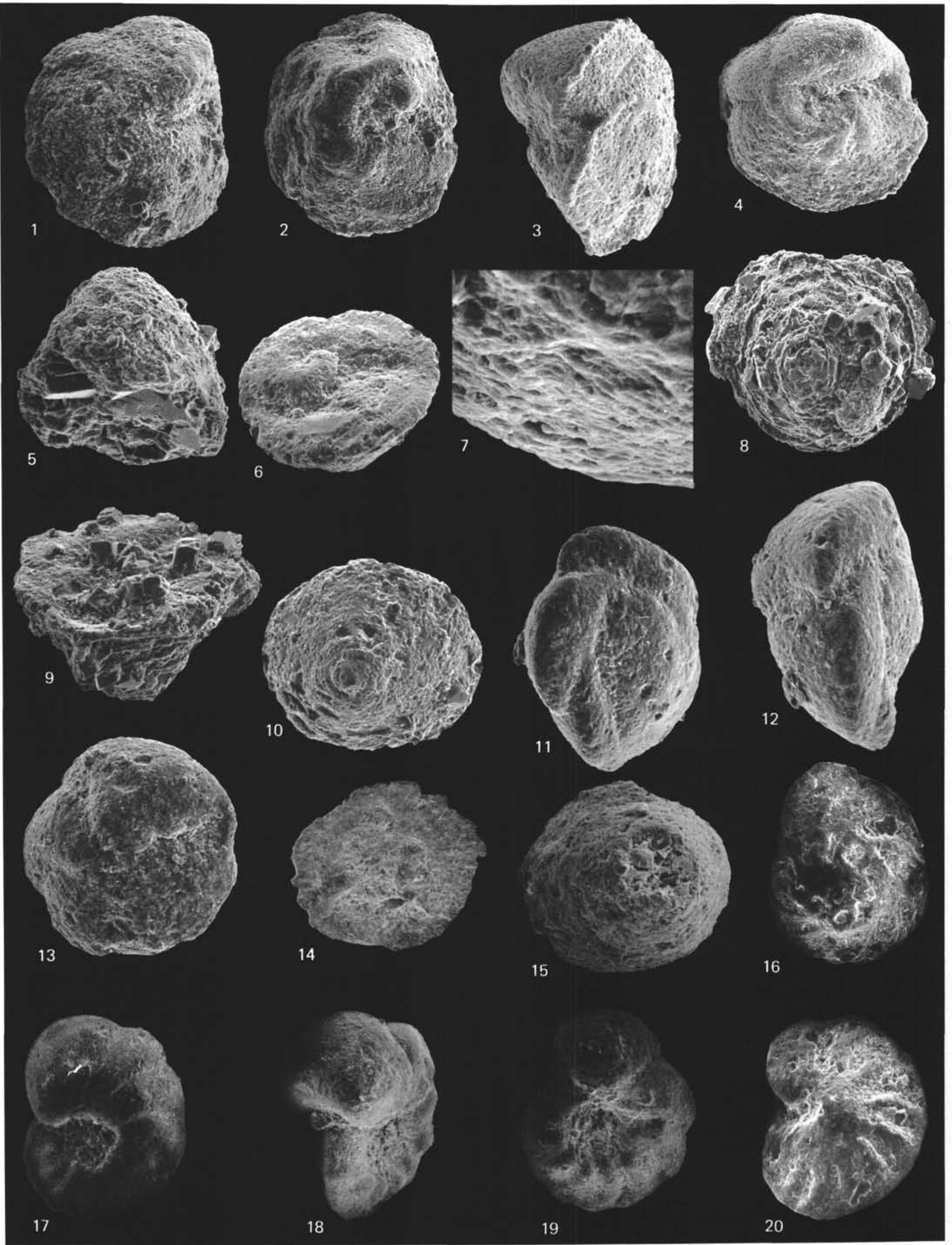

